Global Conferences Series:

Social Sciences, Education and Humanities (GCSSSEH), Volume 2, 2019

The $2^{\text {nd }}$ International Conference on Sustainable Development \& Multi-Ethnic Society

DOI: https://doi.org/10.32698/GCS.0190

\title{
The Use of Frog VLE "Roti Canai" Module in History Subject Learning at Primary School
}

\author{
Mahathir Abu Khalipah ${ }^{1}$, Abdul Razaq Ahmad ${ }^{2}$ \& Mohd Mahzan Awang ${ }^{3}$ \\ ${ }^{123}$ Faculty of Education UKM, MALAYSIA
}

E-mail: mahathir_abukhalipah@yahoo.com

\begin{abstract}
Learning management systems are groups of software designed to support online or local network education. In response to this effort, the Ministry Education of Malaysia has provided a learning management system through the 1BestariNet Project. It is known as Frog Virtual Learning Environment (Frog VLE). "Roti Canai" is the latest module introduced in this system that can be implemented this year. However, the Report of Malaysian Education Development Plan (PPPM) from 2015 to 2018 found that the percentage of Frog VLE use in the most schools was not satisfactory. The main cause is that educators do not have sufficient training, lack of skills and are less aware of the potential of Frog VLE to improve their daily teaching \& facilitating $(\mathrm{PdPc})$ techniques. Therefore, the objective of this study is to discover the potential of the "Roti Canai" Frog VLE module to enhance learning excellence in primary schools especially in History subject. This study also provides a lot of useful information on the potential of Frog VLE and it opens up the scope and need for future research. The study also outlines the features of this module, the best practices and advantages of the Frog VLE "Roti Canai" module in which every primary school teacher can manipulate the privileges that have been bestowed to them.
\end{abstract}

Keywords: "Roti Canai" module, Frog VLE, educators, history subject, primary school

\section{Introduction}

Teaching aids are one of the most important mediums in the classroom. It helps educators as well as launches student teaching and understanding sessions on what they are trying to convey. According to some teaching theories without practice, students are seen to be able to master a new lesson with the use of fuel that combines the use of eyes and ears rather than without it. Effective teaching aids (BBM) depend on the teacher's ability and ability to handle the appropriate tools with a given topic (Jamaliah Jamaludin, 2014). This opinion is supported by Farah Farhana et al. (2019) state that the use of teaching aids (BBM) and effective teaching strategies affect students' understanding and knowledge.

Teaching aids (BBM) and Teaching \& Facilitating $(\mathrm{PdPc})$ are two elements that are closely related to each other. It is the role of an educator to convey knowledge and to engage his students with the knowledge they are trying to convey. Effective Teaching \& Facilitating ( $\mathrm{PdPc}$ ) can be translated through the extent to which educators can produce interactive teaching environment. Innovative and creative teachers should be specially prepared to adopt a new 
mechanism based on their ideas as well as through existing BBM adaptations. The existence of BBM enables the role of educators as facilitators and enhances the effectiveness of student-centered learning with only $25 \%$ of teacher involvement in the classroom.

Acting as a supportive instrument, the teaching aids (BBM) of various tools and equipment can be explored by educators to help improve students' understanding of information. In line with the development of science, innovation, and ICT, BBM instruments continue to grow over time. From the use of black and chalkboard, whiteboards and markers to the use of electronic equipment such as laptops, video, internet, overhead projectors (OHPs), cameras and camera phones. However, several studies have been conducted found that the consumption of fuel in schools is still poor. This opinion is supported by Kamarul Azmi et al. (2011) through a study stated that effective practice of fuel use has not been fully applied in light of the need for educators to devote money, time and energy in providing it.

In line with this, the "Roti Canai" module is a new teaching aids (BBM) introduced by the Ministry Education of Malaysia to further enhance the Learning \& Facilitating $(\mathrm{PdPc})$ session of Malaysian students. This module is designed to help schools achieve the vision of "Achieving student achievement through academic improvement using the Frog VLE". This module is very interesting to study as it is one of the teaching aids that contain Boost Sites and Community Quizzes which greatly helps teachers improve their Learning \& Facilitating (PdPc) quality.

\section{Frog VLE use at international levels}

The conceptualization of E-learning and LMS concepts internationally is in line with the development of computer and internet technologies. People in the world began to connect and communicate through the internet. The need for information-based education is rapidly becoming an urgent need, time; distance and location are no longer a hindrance. E-Learning is growing rapidly, supported by the increasing sophistication of information technology and a better understanding of how to make content and delivery more effective. Besides, various types of support for the ELearning system were introduced to institutional education to meet the student-centred learning paradigm recommended by UNESCO (UNESCO, 1998). Frog VLE is one of the most popular LMSs available in the e-learning world besides ePath, Moodle, Sakai, Edmodo, Class Dojo, and others. Frog VLE is used in schools in 23 countries around the world including France, the United States of America (USA), Qatar, Britain, and Malaysia. Use of Frog VLE in countries other than Malaysia is a school initiative by subscribing to
Frog VLE services from FROG Education to facilitate virtual learning management and assist schoolgirls especially students and teachers in teaching and learning sessions (Frog Education, 2017). Feedback on the use of Frog VLE through articles written by schools in the United Kingdom largely shows that Frog VLE has helped to manage their school's learning management.

\section{Frog VLE in Malaysia}

In Malaysia, 1BestariNet emerged as the initiative of the Ministry of Education Malaysia (KPM) initiative after the Economic Council Meeting no.12/2011 dated 28.3.2011, it decided to be implemented promptly through open tenders taking into account Frog VLE components to accelerate the e-learning approach with more effective integrated management and involving 10,000 schools across Malaysia. To that end, schools are equipped with high-speed Internet access and virtual learning platforms that apply Internet networks as well as access to world-class integrated education solutions. 1BestariNet's vision is to transform the educational platform in Malaysia and bridge the digital divide between urban and rural students by providing quality Internet-based education to all Malaysians (1BestariNet, 2013). This government initiative is entering Phase 2 (20152019) with the enhancement of services to ensure the ICT solutions provided meet the needs of consumers to improve the quality of teaching and learning in all KPM schools through Frog VLE. Virtual Learning Environment (VLE) is also a simple, fun and engaging online web-based learning system. Schools across Malaysia have been provided with Frog VLE for free. Frog VLE is an easy-to-use learning platform and a gateway to a wide range of educational resources and interesting applications from various websites. VLE is also a platform that enables teachers, students and parents, to gain access to the latest educational information and news. However, according to a National Audit analysis of VLE usage based on the number of VLE login schools from March 1 to 31 (2014), VLE usage among schools across the country was low, between $1,956(19.5 \%)$ and $3,358(33.5 \%)$ schools only. For the same period, Audit analysis also found that VLE usage based on student, teacher and parent logins in schools across Malaysia was very low as follows: students between 0.17 to $0.63 \%$, teachers between 0.57 and $4.69 \%$, parents between 0.01 to $0.03 \%$. (State Audit Report, 1BestariNet, 2014).

The percentage calculation of daily VLE usage is made assuming that the number of daily logins is equal to the number of users accessing the VLE. This percentage may be lower because the number of logins recorded in the system does not represent the actual number of users accessing the VLE as a user can log in to VLE more than once daily. Since 
January 2014, the MOE has developed a more aggressive approach to reaching out to teachers to gain their interest in VLE applications. The low use of VLE among teachers and pupils is due to lack of clear policies and monitoring of VLE use from the MOE, lack of exposure to the benefits of using VLE for teaching and learning purposes, 1BestariNet's accessibility makes it difficult for teachers to access VLE during learning times and to update and to include teaching materials in schools. Also, the lack of teaching aids such as laptops and projectors for classroom teaching and the lack of computers provided in the school computer lab contributed to this problem (National Audit Report, 1BestariNet, 2014). According to Nor Azlah Mohd Jaafar and Fariza Khalid (2014) in the Study of Effective Communication Skills among Teachers in the Use of Virtual Learning Environment (Frog VLE), 2014 found that overall statistical findings from the data show that the level of use of Virtual Learning Environment (Frog VLE) is too low. In 2016, access to the internet through the 1BestariNet network and use of the Virtual Learning Environment (VLE) has increased over the three years since its introduction to enable teachers to optimize the world-class knowledge base in the classroom. The increase in the use of Virtual Learning Environments (VLE) signals that students and teachers are ready and accepting technology integration in and out of the classroom (PPPM Annual Report 2016).

\section{Potential use of Frog VLE for learning excellence}

The Frog Virtual Learning Environment (Frog VLE) is introduced to new concepts with integrated ideas and innovations that incorporate technological innovation features that include new ideas, concepts, and strategies that are better than the old and can enhance practice (Roger, 1971 \& Spencer, 1994). Frog Virtual Learning Environment (Frog VLE) as an intranet, online classroom and social space for schools. Viewed as a web-based learning system that resembles real-world education by integrating conventional education concepts where teachers can assign assignments, tests, and scores, while students can submit their homework and check scores obtained through Frog VLE. Files, records, and data can be stored in the cloud accessible anywhere and anytime with Internet access. Users are provided free access to the VLE each time they log in from the Yes network with an automatically generated login ID through data collection from the Student Database Application (APDM). IDs are available for teachers, students and parents to enable information, communication, and online communication to occur between school children. Schools can plan and organize school calendars and then publish activities through online notices (Frog Asia 2016). Improvements in the applications provided and these services are seen to be on going in the Frog VLE learning management system in
August 2012, September 2014 and most recently July 2016 which involved enhancing application functionality and widgets including starting with M-learning elements to facilitate work evaluation homemade via smartphone. For that, 58908 Yes Altitude smartphones are supplied to several states that receive $4 \mathrm{G}$ services (Teacher data plan, 1BestariNet Phase 2, 2016).

Results of a study conducted by Agus, 2009; Srichnyachon, 2014; Wichadee, 2015 categorizes three main types of learning management systems (learning tools, communication tools, and productivity tools). These three types of systems are integrated into Frog VLE with a range of functions and tools that support schools and teachers in the areas of administrative and learning management. Tools for learning skills such as learning sites are built by teachers as well as from E-Materials to create teaching and learning activities and materials. This tool can be accessed through specific widgets including quiz widgets, forms, media, polls, forums, wall, text activity, embed, file drops and external links. Teachers can use widgets to create links to presentations, online discussions, homework, and to collect training provided to students. Feedback, data and answer records, scoring and monitoring student progress can be implemented. The widget app is just as easy as drag and drop and easy to manage. Frog Assignment and Frog Snap through the mobile app also help teachers check student training anytime and upload training directly through smartphones. The presentation material just needs to be embedded on the page using the website link as an example Youtube (Agus, 2009). Whereas to practice quiz form teachers can build quizzes using existing quiz applications or even use quizzes from external links like Kahoot or Quizlets. Student grade data can be stored and recorded in the cloud. Students are allowed to submit assignments or practice until they get the best results. These communication tools are enabled interaction between teachers and pupils, pupils with pupils and even teachers with parents. Through the Widget Walls, Forums and the latest enhancements of frog chat through mobile applications, it enables discussions between students and teachers in informal learning. Frog VLE also uses the Google app as a communication tool between schools and schools through Gmail and Hangouts apps. Online video conferencing can be done in the classroom using Hangouts.

Further productivity tools in the LMS include administrative document management systems, administrative related forms, calendars, questionnaires as well as student Classroom Evaluation (PBD) records storage through Google Drive and Frog Drive storage and a number of other applications making it a useful tool in Frog VLE to meet LMS's ability to administer the Curriculum, store 
teaching materials and use it as a tool for assessing students (Napaporn, 2014; Pardeman \& Suparyanto, 2014). Manipulating pedagogy in Frog VLE based on the basic aim of teaching is to develop students' ability to learn. Here teachers act as mentors and provide opportunities for students to reflect on social and active interactions. The application of constructivism in LMS involves students and learning takes place in social contexts and interaction between peers is an important part of learning (active learning). Through the multimedia communication space allowed in Forum Widgets, Widgets wall, and Google apps usage. Teachers can also use a blended learning approach that combines the conventional method of face-to-face and online, which is a blending of learning patterns between two key elements of blended learning (Mosa al et, 2011) to design teaching within the Frog VLE site. This conceptualized online learning still requires a face-to-face approach between teachers and students, especially in the classroom and at the same time the student's self-directed learning process through online learning. Conventional learning integration with online learning requires the creativity and innovation of teachers to plan learning through a variety of appropriate learning theories based on three essential components of blended learning that are environmental, instructional strategies as well as the diversity of teaching media (Manjot, 2013). The aim is to maximize the understanding of a principle, theory, and knowledge. A student-centred Blended Learning approach only can be fully implemented whereby students can control their learning rate and they can use a variety of technologies online.

\section{The 21st Century Learning Module offered in Frog VLE}

FrogAsia provides a variety of Hub Modules to help teachers get started with Frog VLE's virtual learning platform. It aims to equip teachers with the skills needed to make 21 st Century Teaching and Learning more interesting, engaging and effective in the classroom. There are 10 modules have been introduced in the Frog VLE virtual learning platform. All of these modules are as follows:

\subsection{PIE (Participation, Interaction, Engagement)}

This module guides participants to capture and enhance student engagement within $\mathrm{PdPc}$ through the creation of a new site using 3 widgets, Text, Media and Wall within Frog VLE. This PIE module will also provide an opportunity for teachers to share ideas about classroom management.

\subsection{CHEnDOL (Critical Thinking, HOTS, Engagement and Discussion through Online Learning)}

This CHEnDOL module is designed for teachers who want to inculcate HOTS among students by using online PdPc materials to stimulate thinking and encourage collaborative learning, with the help of 3 widgets (Embed Website, External Link, and Forum).

\subsection{TEH Als (Tech Enhancement for Assessment and Interaction)}

The TEH AIs module is a partnership on how to leverage and customize the use of technology in Teaching \& Facilitating $(\mathrm{PdPc})$ and improve teaching efficiency through the use of Frog VLE through 3 widgets, Poll, Quiz, Form focusing on interaction and assessment aspects.

\subsection{CAKE (Connect and Keep Engaging)}

The CAKE module is designed to empower teachers and students with a creative and innovative way of learning through video conferencing technology with the use of the Frog site which is the Frog Connected Classroom learning concept.

\subsection{PUFFS (Projects Using Frog for Students)}

The PUFFS module is designed for teachers who want to engage students in 21 st-century teaching through projectbased learning using Frog VLE. The workshop also provided an opportunity for teachers to share their experiences and design digital projects for students using specific widgets.

\subsection{CHEF (Communicating and Heading E-learning with Frog)}

The CHEF module is designed specifically for Frog Admin and covers user management tasks towards Frog culture at schools. It enables FrogAdmin to know and share the best practices as FrogAdmin and to experience different modules.

\subsection{GULAI (Game up Learning and Involvement)}

This GULAI module will introduce FrogPlay as a preview application for students with comprehensive quiz content, mini-games, and comprehensive performance reports. It also includes learning methods through continuous performance feedback through the use of the FrogPlay application.

\subsection{NASI LEMAK (FrogAsia Hub Module themed Frog Mobile Applications)}

NASI LEMAK module is a module that covers all the modules related to the YES Altitude smartphone and Frog mobile applications. They consist of Frog Assignment, Frog 
Chat, and Frog Snap. Participants can start a module usage session with any of the sub-modules.

\subsection{FrogBites - (Frog VLE e-training module for teachers)}

The FrogBites e-training module is specially designed for teachers who wish to apply Frog VLE within Teaching \& Facilitating session. It is designed to be easy and flexible to learn and incorporates basic skills using Frog VLE. This module gives teachers the freedom to learn at any time, on their own.

\subsection{Sate (Start and Teach Easily)}

This Sate module allows participants to use Frog to aid learning and compete to make schools, teachers, and students the champions of the Frog Championships. The learning materials provided are free and include Frog Boost and Frog Play applications that are easily accessible to teachers and students.

\section{Creativity Elements in the "Roti Canai" Module}

The "Roti Canai" module is the eleventh and latest module from Frog VLE. It is designed to help schools achieve their vision: to achieve student achievement through the academic improvement of core subjects using the VLE Frog. The result of learning through this module is that all educators will be able to understand how to use Boost and Quizzes to help improve student achievement and practice the lesson plans that have been developed with the workshop participants. Besides, the developed daily lesson plans can be applied in the classroom and utilize the FrogHub application for professional development purposes.

\begin{tabular}{|c|c|c|c|}
\hline $\begin{array}{l}\text { Teacher } \\
\text { attends } \\
\text { "Roti } \\
\text { Canai" } \\
\text { module } \\
\text { work- } \\
\text { shop. }\end{array}$ & $\begin{array}{l}\text { Teacher } \\
\text { plans \& } \\
\text { construct } \\
\text { s lesson } \\
\text { plan } \\
\text { with } \\
\text { existed } \\
\text { materials }\end{array}$ & $\begin{array}{l}\text { Teacher } \\
\text { conducts the } \\
\text { PdPc using the } \\
\text { existed teaching } \\
\text { aids \& will be } \\
\text { monitored by the } \\
\text { school } \\
\text { administrator. }\end{array}$ & $\begin{array}{l}\text { Shares } \\
\text { and gets } \\
\text { feedback } \\
\text { in Meet, } \\
\text { Share \& } \\
\text { Learn. }\end{array}$ \\
\hline
\end{tabular}

FIGURE 1: Flow chart of teacher professional development

\subsection{Boost Website}

This website is a Frog application that containing hundreds of pages following the Ministry Education of Malaysia's syllabus. It is built by selected teachers according to special guidelines. Teachers will use it in PdPc and assign it to students. Students will also make reference and practice using Boost Pages.

\subsection{Community Quizzes}

It comprises a repository of thousands of quizzes created by teachers. They will be sharing with other teachers from across the country.

\subsection{Goals Meet, Share \& Learn}

After teachers run $\mathrm{PdPc}$, they will share their reflections, especially on the delivery aspect, getting feedback from other teachers from other schools. Through this session, they will be able to learn new skills and applications systematically.

\section{Conclusion}

The increase in the use of Virtual Learning Environments (VLE) in 2016 has shown that students and teachers are ready and accepting technology integration in and out of the classroom. Technology classrooms equipped with digital learning tools such as computers and mobile devices offer more courses, learning experiences, and learning materials. Students have access to learning 24 hours a day, seven days a week as well as strengthening 21 st-century skills; further enhancing student engagement and learning, and driving learning progress. The provision of interesting learning and teaching aids is important to enable students to explore alternative learning materials to enhance their knowledge and skills. The Ministry Education of Malaysia has increased efforts to improve the system's efficiency by focusing on redefining and optimizing the budget towards maximizing student achievement, improving the Ministry's internal skills and competencies, improving school infrastructure and maintenance, strengthening educational databases to facilitate decision-making and encourage use of VLE to enhance learning ability. In addition, the Ministry Education of Malaysia also strives to improve the efficiency of operating low-performing schools. Other notable efforts to complement the above activities include monitoring of state and district VLE usage through PKG and PPD, training and Frog VLE workshops at the school level, holding ongoing seminars to promote use of VLE at state level and validating the content of VLE learning modules generated by teachers for quality assurance (PPPM Annual Report 2016). 


\section{References}

[1] 1BestariNet. 21 August 2019. Mengenai Kami, Kementerian Pendidikan Malaysia. http://1bestarinet.net/?page_id=205 [15 November 2016]

[2] Agus D. Priyanto.(2009).Facilitating Language Learning With Lms: (A Brief Review On Blackboard And Moodle) http://agusdepe.staff.uns.ac.id/2009/04/06/facilitatinglanguage-learning-with-lms-abrief-review-onblackboard-and-moodle/[22 March 2019]

[3] Bergman dan Sams (2012). Flip Your Classroom: Reach Every Student in Every Class Every Day. https://escolaecofeliz.files.wordpress.com/2015/12/flipyour-classroom.pdf [15 April 2019]

[4] FROG asia.(2016). Frog Vle. Kuala Lumpur, https://frogasia.com/ms/frogvle/FROG

Education.(2016).About Us. Halifax. UK, https://www.frogeducation.com/about [16 May 2019].

[5] Farah Farhana Rusli, Mohd Anuar Ramli \& Firdaus Abdullah Fatah. 2019. Penerimaan Pelajar Institut Pendidikan Guru (IPG) terhadap Elemen Fiqh Semasa dalam Kursus Pendidikan Islam. Jurnal Islam dan Masyarakat kontemporari . 20(1): 29-48

[6] Jackie Gerstein. (2012). Flipped Classroom: The Full Picture for Higher Education, https://usergeneratededucation.wordpress.com/2012/05/1 5/flipped-classroom-thefull-picture-for-higher-education/ [25 August 2019].

[7] Jamaliah Binti Jamaludin. 2014. Kesediaan Guru Kolej Vokasional dalam Pengajaran Amali Teknologi Elektronik di Negeri Pahang. Tesis Sarjana. Universiti Tun Hussein Onn, Malaysia.

[8] Justin Ferriman.(2015). History of the LMS. https://www.learndash.com/history-of-the-lms/ $\quad[25$ December 2018]

[9] Kamarul Azmi, Mohd Faeez, Ab. Halim \& Mohd Izham Mohd Hamzah.( 2011). Amalan Penggunaan Bahan Bantu Mengajar dalam Kalangan Guru Cemerlang Pendidikan Islam Sekolah Menengah di Malaysia. 2011. Journal of Islamic and Arabic Education. 3(1):59-74.

[10] Kementerian Pendidikan Malaysia. (2014). 1bestarinet For Eurosai Cube, Maklum balas Laporan Audit Negara Kementerian Pendidikan Malaysia.(2016). Amalan Pendidikan Alaf Baru dengan Telefon Pintar Yes Altitude : Kuala Lumpur : YTL Communication.

[11] Kementerian Pendidikan Malaysia.(2016). Distribution of Teacher Data Plan (Individual Account \& YES 4G Device): Kuala Lumpur : YTL Communication.

[12] Kementerian Pendidikan Malaysia. (2013). Pelan Pembangunan Pendidikan Malaysia 2013-2025, Kuala Lumpur: Bahagian Teknologi Pendidikan.
[13] Kementerian Pendidikan Malaysia. (2016). Laporan Tahunan PPPM 2016. Pelan Pembangunan Pendidikan Malaysia 2013- 2025 : Putrajaya

[14] Manjot Kaur.(2013). Blended Learning - Its Challenges and Future. Procedia - Social and Behavioral Sciences, 93, 612-617.

[15] Mishra, P., \& Koehler, M. (2007). Technological pedagogical content knowledge (TPCK): Confronting the wicked problems of teaching with technology. In C. Crawford et al.(Eds.), Proceedings of Society for Information Technology and Teacher Education International Conference 2007 (pp. 2214-2226). Chesapeake, VA: Association for the Advancement of Computing in Education.

[16] Mosa, A., Yoo, I., \& Sheets, L.(2011). A Systematic Review of (ealthcare Applications for Smartphones.BMC Medical Informatics and Decision Making, 12,67.Prosiding Konvensyen Kebangsaan Sekolah Kluster Kecemerlangan 189.

[17] Napaporn, S.(2014). Elf Learners' Perception of using Lms. The Turkish Online Journal of Educational Technology, 13(4),30-36.

[18] Nor Azlah Mohd Jaafar \& Fariza Khalid.(2014). Keberkesanan kemahiran komunikasi di kalangan guru dalam penggunaan persekitaran pembelajaran maya ( Frog VLE): Dlm. Aliran Terkini Dalam Pengajaran Sumber \& Teknologi Maklumat: Impaknya ke atas Penyelidikan dalam Pendidikan. Bangi: Penerbit Fakulti Pendidikan, UKM.

[19] Pardeman, B \& Suparyanto,T.(2014). A systematic approach to improving e-learning implementation in high schools. The Turkish Online Journal of Educational Technology, 13(3),19-26.

[20] Rogers Everett M.(1971). Diffusion Of Innovations :Third Edition https://teddykw2.files.wordpress.com/2012/07/everettm-rogersdiffusion- of-innovations.pdf [29 September 2019].

[21] Srichanyachon, N.(2014). Efl Learners's Perception of Using LMS. The Turkish Online Journal of Educational Technology, 13(4),30-35.

[22] UNESCO .(1998). World declaration on Higher Education for the twenty-first century: vision and action. Proceedings of the World Conference on Higher Education, Paris, 5-9 October, 1998.

[23] Wichadee.S.(2015). Faktor Related to Faculty Members' Attitude and Adoption of a learning Management System. The Turkish Online Journal of Educational Technology, 14(4),53-61

[24] W. R. Spence.(1994). Innovation: The Communication of Change in Ideas, Practices and Products London: Chapman \& Hall, 72. 